\title{
TAN MALAKA'S ARREST: AN EYE-WITNESS ACCOUNT
}

\author{
Aboe Bakar Loebis
}

Born in Pandan Gadang, in the region of Suliki, West Sumatra, Ibrahim Datuk Tan Malaka was educated at the teachers' school in Bukit Tinggi. Then for further study he went to Holland, where he was exposed to political concepts that inspired him with the spirit of revolutionary nationalism.

When he returned from Holland in late 1919, he taught school for a while in a plantation in East Sumatra. But, unable to bear the sight of contract coolies working under miserable, inhuman conditions at the plantations of that region, he quit teaching. What he saw of the coolies' sufferings increased his fervor for communism. He moved to Semarang, where he quickly rose in the ranks of the Indonesian Communist Party (PKI), eventually replacing its leader Semaun, who went to Moscow. But accused of delivering inflammatory speeches during a strike of pawn shop workers, Tan Malaka was arrested by the Netherlands Indies government and exiled to Holland.

In the early years of the Comintern Tan Malaka caused a furor by declaring that Communists in colonial countries should work together with religious groups-Islamic organizations in the case of Indonesia-peasants, and the petit bourgeoisie in the struggle against capitalism and colonialism. He justified this idea by noting that, in colonial countries, it was almost impossible to find proletarian industrial workers, as there were almost no industries there. In 1923 Tan Malaka was appointed the Comintern's first representative in Southeast Asia with his headquarters in Canton.

When the PKI planned an uprising in 1926, he argued unsuccessfully against it . He had just written Naar de "Republiek Indonesia" [Toward a Republic of Indonesia] the previous year. And in 1926 he wrote a book, Massa Actie, also arguing against the contemplated PKI uprising, sure that the Netherlands Indies government would easily crush it. He was so disgusted with the policies of the PKI that he left the Comintern and the PKI and with several friends, including Djamaloedin Tamin and Soebakat, he established the Republic of Indonesia Party (Partai Republik Indonesia, Pari) in Bangkok in July 1927.

This party, however, could not flourish under the constant harassment from the Dutch and British police. The Dutch police captured Djamaloedin Tamin and Soebakat, who died 
in police custody. Djamaloedin Tamin was exiled to Boven Digoel in New Guinea. Tan Malaka sought refuge in China, from where he had to flee again ahead of the Japanese advance, then settling in Singapore where he got a teaching job at a Chinese school. When the Japanese attacked Singapore, Tan Malaka made his way to Sumatra and then to Java, where he worked in a coalmine company in Bayah, Banten. And again he saw human misery, this time in the plight of the miners, and the romusha in general. The romusha were workers forcibly recruited from among village youths. Bung Karno was an active advocate of that recruitment program, but Tan Malaka worked to alleviate the romusha's plight, and denounced the Soekarno-Hatta leadership for its policies on the forced labor and for cooperating with the Japanese.

Before the outbreak of the war Tan Malaka had become a legendary figure. A popular tale was that he could enter and leave the Dutch East Indies, particularly Sumatra, as he pleased. An author wrote a fictional account of his activities, calling him Pacar Merah, after the hero of an English story, "The Scarlet Pimpernel" - a man that the police hunted assiduously but could not capture. Tan Malaka personified the nationalist struggle and was mythologized as such.

During the 1930s, the Dutch police themselves spread many stories about Tan Malaka to lure his followers out of hiding and then arrest them once they surfaced. When Tan Malaka finally emerged among the people during the revolution for independence, no one could believe that he was the real Tan Malaka. Mistaken for an impersonator, he was arrested by the military police in Mojokerto.

In June 1945 the BPP (Badan Pembantu Keluarga Peta) of Bayah delegated Tan Malaka as its representative to a BPP meeting in Jakarta.Though this meeting was banned by the Japanese, while in Jakarta Tan Malaka was able to meet with several pemuda leaders such as Chaerul Saleh, Soekarni, B.M. Diah, Anwar, and Harsono Tjokroaminoto, without revealing who he was. Two months later he was again delegated to represent the Bayah pemuda at a meeting between the pemuda and Bung Karno, as head of the Jawa Hookoo Kai. He arrived in Jakarta on August 15, 1945. While in Jakarta Sajuti Melik arranged for him to meet with President Soekarno at Dr. Suharto's house. According to Tan Malaka, at that meeting Soekarno said to him: "If I no longer am capable, then I will yield the leadership of the revolution to you." Then Soekarno gave him some money. Several days later at another meeting, this time at the house of Dr. Muwardi, leader of the Barisan Pelopor, Soekarno repeated his statement about the possibility of yielding leadership of the revolution to Tan Malaka.

Soekarno might really have said this because at that time, there were rumors that he and Hatta would be arrested by the Allies for collaborating with the Japanese. He wanted to see the struggle continued for defending and maintaining the state that had just been born.

When Tan Malaka left Jakarta on October 1, 1945 he had in his pocket a statement signed by Soekarno and Hatta, that if they no longer were capable of leading the revolution, they would yield the leadership to him, Sjahrir, Iwa Kusuma Sumantri, and Wongsonegoro, so not to Tan Malaka alone.

During these months he never succeeded in meeting the pemuda leaders at their headquarters in Menteng 31 or in Parapatan 10. This is strange, considering that he had met with Subardjo, Sajuti Melik, Dr. Muwardi, and Soekarno himself, and all of them certainly knew where and what Menteng 31 or Parapatan 10 were. Thus he failed to place himself where the real struggle was: he was unable to influence the processes and actions that led to the 
Proclamation of Independence and its critical aftermath. Feeling that, with the arrival of the British forces, Jakarta was no longer safe, he went to Bogor, still using the alias Husein.

It was only after his arrival in Bogor that Soekarni and Adam Malik approached him. Then they brought to meet him Bapak Alim, an old teacher who had been his classmate at the teachers' training school in Bukit Tinggi. Only then did Tan Malaka understand their behavior toward him; for in the past an impersonator had, on several occasions, emerged at the bidding of the Dutch police and later the Japanese kempeitai to lure Tan Malaka's followers and sow confusion in the nationalist struggle.

After that, a group of medical students from Parapatan 10, headed by Tadjuludin, met with Tan Malaka. They asked him what politics to pursue now that we already have our Republic? His answer was truly brilliant. He said in English: "We must follow a nationalist policy strongly colored by socialism" (kita harus menjalankan suatu politik nasionalis yang sangat diwarnai oleh sosialisme). From Bogor Tan Malaka moved to Serang, and there he was visited by Sjahrir and his friends, including Djohan Sjahroezah, Kartamuhari, Sasra, Sugra, and Jamil. They discussed problems of the revolutionary struggle at that time, without, of course, reaching complete agreement on every problem. On that occasion Tan Malaka and Sjahrir had a separate conversation, during which, according to Jamil (colonel retd.), Tan Malaka invited Sjahrir to help him remove Soekarno from the leadership of the revolution, because Soekarno had shown he was not capable of leading it. Sjahrir replied: "If you can show me that you have even 5 percent of the influence that Soekarno enjoys, I will join you. I advise you to travel first throughout Java to see the actual situation, and only after that decide the attitude and steps that need to be taken."

When the group came back from Serang, I asked Djohan Sjahroezah how the meeting had gone. At first, Djohan would not say much, except that the Tan Malaka he had met at Serang was quite different from the Tan Malaka whom he had long admired from afar. "Can this be the attitude of a revolutionary?" he wondered. Only later, did he pour out his disappointment over Tan Malaka's answers to the questions put to him. From those answers, Djohan said, it was clear that Tan Malaka had a large ego. During their talks, Djohan recalled, Tan Malaka always referred to himself as T.M. Djohan had now lost an idol. That meeting in Serang created a distance between Djohan and his comrades in the struggle, Soekarni, Adam Malik, Pandu Kartawiguna, and Maruto Nitimihardjo, who still strongly admired Tan Malaka.

Meanwhile, in the next few weeks, Tan Malaka journeyed around Java. On arriving in Mojokerto, he revealed his identity and was quickly arrested by the military police, who mistook him for one of the imposters. Fortunately for him, Djohan Sjahroezah, who had returned to Mojokerto from Jakarta heard about the arrest. He used his influence to get Tan Malaka released. Later Tan Malaka was taken to Surabaya and after fighting broke out there withdrew to Malang. In Malang initial preparations were made to unite the various groups struggling against the imperialist forces, and finally on January 3-5, 1946, an organizational meeting was held in Purwokerto, attended by representatives of 138 organizations, where it was decided to form a broad front called the "Persatuan Perjuangan." The participants held another meeting in Solo on January 15-16 where the proposed draft program for the Persatuan Perjuangan was discussed and approved.

More important than the organization formed at Purwokerto, was the fighting spirit that it inflamed, a spirit that was opposed to efforts to seek recognition for the Republic of Indonesia through peaceful negotiation. The idea was to oppose the Allies, to oppose the Dutch, and confiscate the possessions of the enemy. The revolution had to continue. Another theme 
that surfaced at that congress was that the leadership of the revolution had to be passed on to Tan Malaka, partly on the basis of the Political Testament of October 1, 1945. My discussions at that time with Soekarni and Adam Malik clearly indicated this.

The second congress in Solo, attended by 141 organizations, produced a political program, called the "Minimum Program" and a table of organization and working procedures. Among the guests was Commander in Chief General Soedirman.

The Minimum Program of the Persatuan Perjuangan drawn up at the Congress contained 7 items:

1. A recognition of 100 percent independence.

2. A People's Government whose goals must coincide with the wishes of the people.

3. A People's Army, whose goals must coincide with the wishes of the people.

4. Disarming the Japanese Army.

5. Settlement of the question of European internees.

6. Confiscation and operation of the enemy's plantations.

7. Confiscation of the the enemy's industries (factories, workshops, mines. etc.)

This minimum program was obviously very radical, and whether it could be implemented was extremely doubtful. The program demanded that the Dutch immediately grant recognition of 100 percent independence, which really meant that the Dutch would first have to surrender, and only after that would we agree to discuss Indonesian-Dutch relations further. In explaining this program, Tan Malaka asserted several times that all foreign forces had first to be expelled from the land and waters of Indonesia.

But how could negotiations be carried out with the Dutch after confiscating their plantations and industries?

Empowered by the KNIP to negotiate with the Dutch, the government too aimed at achieving 100 percent independence. Whether this could be done at once or in several stages, would be the subject of negotiations. So the Minimum Program was inconsistent with the government position, even if the final aim was the same: 100 percent independence.

Meanwhile, the political atmosphere all over the country was heating up, as the Persatuan Perjuangan held meetings and demonstrations against the government's policy of negotiations. At the end of February, when the KNIP held its second session in Solo, tension rose even further. At the KNIP session Sjahrir resigned as Prime Minister, and the Persatuan Perjuangan demanded that it be given the mandate to form a new government, with its Minimum Program as the government program.

Rejecting these demands, President Soekarno again invited Sjahrir to form a new government, with the following program:

1. Negotiate on a basis of recognition of 100 percent independence.

2. Prepare the people in all political, economic and social fields to defend the sovereignty of the Republic of Indonesia

3. Organize a central government and regional governments that are democratic.

4. Strive energetically to perfect the distribution of food and clothing 
5. Concerning the industries and plantations, the Government will take steps to fulfil the intentions of Paragraph 33 of the 1945 Constitution.

The essence of that program was a willingness to negotiate with the Allies and the Dutch. To accommodate slightly to the position of the Persatuan Perjuangan, the committee that formulated the Government program, chaired by President Soekarno himself, stressed that negotiations would be carried out on the basis of recognition of 100 percent independence. This was also what the Persatuan Perjuangan wanted, but the spirit behind the government demand for 100 percent independence was vastly different. The Persatuan Perjuangan rejected the program, and prohibited its members from joining the government.

The Persatuan Perjuangan stepped up its agitation against the Government, eroding the creditiblity of the Republic's negotiators. In arguing for the expulsion of the Allied Forces, Tan Malaka's supporters asked: "What is the point of talking with a burglar that has already broken into our house? The Allies must be ejected from the land and driven into the sea with bambu runcing (sharpened bamboo spears).

It was a politics of fantasy, this call for the people to confront an army that had just won a war and was still fully equipped, well supplied, and combat ready. Such a policy would accept extreme sacrifices and great numbers of victims. The terrible carnage that would follow would also inevitably threaten the very existence of the Indonesian Republic that was still building up its strength.

The government wanted to negotiate precisely to demonstrate to a world already fed up with war, that this young nation of Indonesia had only the most peaceful intentions. And even if an armed struggle proved inevitable, at least the period of negotiations would buy time so that the Indonesian Government would be better prepared for the conflict.

What Tan Malaka and his group wanted was for the Dutch and the Allies to surrender unconditionally while the Dutch plantations, industries, and other properties were seized. In the view of the Republic's leaders, this would give the world the impression that the new authorities in Indonesia were a gang that had no respect for international law. And this, precisely, was the propaganda line of the Dutch, even while the government was trying to project to the world that Indonesians were a highly civilized people with such a level of cultural achievement that they had built the Borobodur temple at a time when the Dutch were still dressed in tree bark.

On March 10, 1946 I happened to be in Jakarta and was discussing the situation with Prime Minister Sjahrir. He said that it was very difficult to conduct negotiations in such an atmosphere, for his delegation could hardly appear credible while the continuous agitation against negotiation was spreading throughout the country. It had to be stopped. From Sjahrir's words, I concluded that he meant that the agitators had to be stopped and that either their organization had to be dissolved or they would have to be detained.

With this conclusion having been reached, I returned to Yogya, and immediately took up the matter with Soebadio [Sastrosatomo]. We then went to the Interior Minister, Dr. Soedarsono to report my conversation with Sjahrir. The three of us, together with Imam Slamet (Bok), then went to Solo to meet with Minister of Defense Amir Sjarifuddin who was confined in a hospital. When we met at the hospital, the two ministers decided to order Tan Malaka's arrest and that of the other leaders of the Persatuan Perjuangan. The letter of authority for the arrest, signed by both ministers, was addressed to Imam Slamet and myself. Subsequently we reported all this to President Soekarno, who gave his approval and 
also Rp. 100,000 Orips to carry out the operation. He also provided us with a car, lent for the purpose by State Secretary Abdul Gafar Pringgodigdo.

In the morning of March 16, we left for Madiun, where the Persatuan Perjuangan was to hold a mass rally the following day. On our arrival, Imam Slamet went to police headquarters to ask assistance in carrying out the arrest on the basis of the letter of authority. The police said they could not help us, and later, when we went to see him, Lt. Col. Sumantri, commander of the TKR regiment, gave the same answer.

At that time the Republic was not yet a year old, and the instruments of state were not yet functioning properly. Imam Slamet and I, however, could not help but feel frustrated. Then I remembered that around Madiun the forces of Pesindo were holding military exercises. So I went to Pesindo headquarters, at the Redjo Agung sugar factory compound. Practically the whole Pesindo leadership was there, including Pramudji, Commander of Pesindo forces, and I explained to them my purpose in Madiun and the problems I was encountering. Pramudji immediately assured me that he would give me whatever help I needed, and I asked that he close the city of Madiun to block the escape of the Persatuan Perjuangan leaders. Since the operation itself was government business, I asked him not to interfere or carry out the arrests himself. He agreed, and after that pulled his forces out of the city, deploying them just outside the city limits. In his book, Dari Penjara ke Penjara (From Jail to Jail), Tan Malaka claimed that the square where they were holding the rally was surrounded by militia armed with machine guns. But this was not true.

From Redjo Agung, not exactly knowing what to do next, I returned to the hotel, where I met Anto Sulaiman. When I told him why Imam Slamet and I were in Madiun and the problems we were encountering, he suggested that I should go to the commander of the Madiun Military Police, Major Sunadi, who had in fact been a schoolmate of mine at the AMS B in Yogya. After reading the letter of authority, Major Sunadi said that he could carry out the arrest on the basis of the letter, so I left the implementation in his hands.

I attended the mass rally in the square. This alerted members of the Persatuan Perjuangan who knew me as a pemuda from Government circles. Experienced underground fighters, they instinctively sensed that something was going to happen. So immediately after the meeting they dispersed, and spread out all over the city. If one had a vehicle, it was not difficult to escape from Madiun by the many roads that led out of the city. But since they had no vehicle, the only way out for them was by train, and there was only one train going to Yogya that evening. Major Sunadi stationed his men at the railway station. When the train was about to leave, one by one the leaders of the Persatuan Perjuangan showed up, and the Military Police could easily arrest them. Those detained included Abikusno Tjokrosujoso, Moh. Yamin, and Chaerul Saleh. Tan Malaka did not appear, nor did Soekarni.

Meanwhile, Imam Slamet and I visited the Resident/Head of the Madiun Region, Susanto Tirtoprodjo, to tell him of our mission and what was happening at that time in his region. He was shaken by our report, but when we showed him the letter of authority he calmed down.

At this point, K.H. Wali Alfatah arrived and apprised Susanto Tirtoprodjo of the arrests of the Persatuan Perjuangan leaders, expressing concern for the safety of "our old man" meaning Tan Malaka. If his safety were guaranteed, Wali Alfatah said, then "our old man" was willing to present himself to the Resident. 
Susanto had to tell him that he was not involved in the arrests, indicating that Imam Slamet and I were the ones authorized to carry them out. Kiai Wali Alfatah asked the reason for the arrests, and I said that I didn't precisely know, but that perhaps the agitation led by Tan Malaka and his friends was threatening to derail the negotiation efforts of the Government. The Kiai then asked whether Tan Malaka would be taken to Yogya to meet President Soekarno, and I told him clearly that there was no order for this. I further stressed that he should convey to "our old man" that I guaranteed his safety. I asked the Kiai to give my name to Tan Malaka because I was sure he knew me.

Kiai Wali Alfatah left the residency and we waited. After an hour, he returned, this time bringing with him Tan Malaka, Soekarni, and two guards armed with sten guns. I told Tan Malaka of the contents of the letter of authority. I made no promise that he would be taken to Yogya to meet and negotiate with President Soekarno. This matter needs to be stressed, because in his book Dari Penjara ke Penjara, Tan Malaka claimed that he surrendered because he was promised to be taken to Yogya to have discussions with President Soekarno. As I see it, K.H. Wali Alfatah came to the Resident to seek protection for Tan Malaka. But he could not do so because we were talking with the Resident at the time. And it was Tan Malaka himself who was anxious to meet with President Soekarno.

That same night we took Tan Malaka and Soekarni to Solo, with a guard from the Military Police. Major General Djoko Soejono, head of the Biro Perjuangan of the Ministry of Defense also traveled with us. He was not involved at all in the operation, but when he heard of the arrests, he immediately sought an explanation at the Military Police headquarters; then he joined with us on the journey to Solo.

That journey of only 80 kilometers took all night as our car or some other car in the convoy would get a flat tire every few kilometers. All the time Soekarni kept saying that the Kedu militia had already been informed of the developments in Madiun, and they were ready to rush to the rescue. As the convoy suffered more flat tires, the tension increased, as we feared that Soekarni might not be bluffing. I warned Soekarni that if there were an attack from the Kedu militia, he would be the first victim, and he kept quiet after that.

Tan Malaka's two young guards had accepted my explanation that I was just taking over the chore of guarding "our old man." (I happened to know them well during the Japanese occupation at Pasar Senen when I was staying at the asrama at Parapatan 10. After that we were together in small fire-fights in the Senen and Keramat area against Ambonese soldiers from Battalion $X$.) They slept soundly throughout the journey.

In Solo, we turned Tan Malaka over to the Solo Military Police, and then went to report to the Minister of Defense, Amir Sjarifuddin, at the hospital. Imam Slamet and I got irritated with Djoko Soejono who tried to give the minister the impression that it was he who had carried out the arrests.

After that we hurried to Yogya to report to President Soekarno that we had accomplished our mission. From the President's residence, we returned to the pemuda headquarters in Pathook, and at once fell asleep because we were so tired. I slept for more than 24 hours; when I woke up, it was not the next day but the day after that..

In his book Dari Penjara ke Penjara, Tan Malaka made it appear that his arrest was based on a letter from the Indonesian negotiating delegation. But it must be emphasized, as the foregoing account indicates, that, in fact, it was the Interior Minister and the Minister of Defense who made the decision to arrest him on the basis of my report on my discussions with Prime Minister Sjahrir concerning the Persatuan Perjuangan's agitation and its impact 
on the negotiations. President Soekarno approved or agreed to the decision, and the funds for the operation came directly from him, while State Secretary Pringgodigdo lent us his car for the operation.

Neither is it true true that there was a promise that Tan Malaka would meet with President Soekarno. If this was the intention why should there be an arrest? He would not have had to be arrested if Soekarno wanted to see him. Soekarno could have invited him and surely he would have come straight away.

For years afterwards, Tan Malaka's followers constantly denounced Sjahrir for this arrest. When Adam Malik became Foreign Minister and I became his assistant, I explained to him on a number of occasions that if he was offended by Tan Malaka's arrest, he should not direct his ire at Sjahrir, but at President Soekarno. It was Soekarno who funded the arrest and arranged for its transportation requirements.

From his writing it is clear that Tan Malaka longed to take over the leadership of the revolution from Soekarno-Hatta. When he was freed from jail, at the time of the PKI revolt in Madiun in September 1948 and later after the Dutch launched their second military aggression, he again agitated to demonstrate the bankruptcy of the Soekarno-Hatta leadership. Since Soekarno-Hatta had been captured by the Dutch, he claimed that, based on the political testament of October 1, 1945, he should now lead the revolution. He could not have chosen a worse time for such a move: it sowed confusion and restlessness and could have even led to chaos among the Indonesian people who were then bracing themselves against the Dutch attack.

Finally Tan Malaka was captured and shot to death in a place close to Mojo village on the banks of the River Berantas in East Java. I have never found out who ordered the execution. According to some sources, Tan Malaka was killed by a unit called Macan Kera, which was part of Surachmad's Brigade. Colonel Sungkono, Panglima of East Java, contrary to some reports, stated that he did not order the execution. Tan Malaka's body was never found.

Thus came to a tragic and sad end a revolutionary leader who in 1925 had already written a book Towards a Republic of Indonesia and who formed a party called Partai Republik Indonesia, but did not live long enough to see his idea of it become a full-fledged reality. What made it the more tragic was that he died trying to take over the leadership of the revolution in order to guarantee the continued existence of that Republic.

Tan Malaka lived more than twenty years in exile, in jail, or in hiding. He lived in a world full of ideas, a troubled world of dreams and fantasies of a utopia. It was a solitary world. Because of this, it should not be surprising if he did not always think or act on the basis of the reality of the situation and atmosphere of the time. Furthermore, he was surrounded by radical followers, like Soekarni, who thought nothing of the consequence of his radicalism. Men like him wanted to spread their own radical ideas through Tan Malaka, who had been cut off too long from the struggle of the Indonesian people.

But whatever his deficiencies and his weaknesses, Tan Malaka was a courageous and brilliant nationalist fighter, thinker, and theoretician whose ideas were decades ahead of their time.

In recognition of his contribution as a nationalist fighter who was among the first to envision the Republic of Indonesia before anyone else thought of it, the Government of the Republic of Indonesia declared Tan Malaka a Hero of National Independence on March 28, 1963 through Presidential Decree No. 53, 1963. 